UDK 316.74:276.2(73)

\title{
CROSSING CULTURAL FRONTIERS: REPRESENTATIONS OF THE AMISH IN AMERICAN CULTURE
}

\author{
Maja Štekovič
}

\begin{abstract}
The paper deals with the typology of Amish fiction, representations of the Amish in literature, and the roles of authors, publishers and readers. Special attention is dedicated to the role of film directors as cultural travellers when crossing cultural frontiers by entering the Amish cultural milieu. The paper also presents a more critical view of the Amish by demonstrating how the perception of the Amish groups has changed with time - from victims of religious persecution in their homeland to becoming highly romanticised people in the Land of Liberty via literature and film.
\end{abstract}

Key words: Amish culture, American culture, Amish fiction, evangelical Christian publishers, romanticizing, Otherness, film representations, cultural frontier, cultural travellers.

The Amish ${ }^{1}$ arrived to Pennsylvania in the early 1700s in search of religious freedom, which they had been denied in their homeland. It seems as though it were a story both highly improbable and unimaginably remote, but the Amish and other Anabaptist groups used to be "executed by civil and religious authorities" (Kraybill $1989,4)$ on the territory of present day Switzerland. Kraybill explains that in order to escape torture, burning, drowning, imprisonment and harassing, the so-called Anabaptist heretics were forced to seek shelter in Moravia, Alsace, the Palatinate and the Netherlands before finally leaving Europe and finding peace in Northern America. However, even with the arrival of the Amish to the Land of Liberty, they did not remain in one place, but they kept migrating around the new homeland. Some Amish communities proved to be amenable to the idea of migration and were willing to cross the Canadian border in search of fertile and arable land on which the church members could survive. Seen in this context, the Amish represent a religious minority group which was forced to leave their place of origin, cross the borders and explore the hitherto little known American frontier. According to Igor Kopytoff, professor of anthropology,

\footnotetext{
${ }^{1}$ The name 'Amish' is usually used synonymously with Old Order Amish, denoting one of the most conservative Amish groups whose members do not use electricity, travel with a horse and buggy and communicate in a German dialect.
} 
[...] frontier areas are indeed stages for new ethnicities, in that they offer the freedom to construct the kind of society the settlers desire. On the other hand, it is very likely that these new societies would be culturally conservative, since people rarely transcend their culture. Frontier cultures thus become repositories of values that have become obsolete in the [homeland] itself (quoted in Rösler, Wendl 1999, 5-6).

Although initially faced with religious intolerance in their old homeland, the Amish population has kept growing in America; it has, in fact, doubled in the past 20 years. According to The Young Center for Anabaptist and Pietist Studies at Elizabethtown College the number of Amish members and their children has increased from 5,000 in 1900 to $261,150^{2}$. On the outside, it may seem that the Old Order Amish groups of the $21^{\text {st }}$ century represent the epitome of cultural conservatism by leading their life in a rather similar manner as the first Amish settlers; and whereas this might be true for the Amish religious life, it would be erroneous to claim that modernity with its technological advances has not had any impact on the life in Amish communities at all - they too use washing machines and telephones only with more restrictions. Despite certain differences among Old Order Amish communities, a vast majority avoid using modern conveniences such as electricity - provided by public utility companies - and driving cars; instead they prefer travelling in horse-drawn buggies. Another crucial element that clearly differentiates the Amish from non-Amish people is the simple attire they accepted as their way of dressing. However, even though the Amish appear to be "remarkably uniform to the outsider [one] cannot know how much the customs and rules of one community differ from those of another" (Hostetler 1993, 277). In Hostetler's book Amish Society, for instance, there are two photographs of two Amish men, one showing "An Amishman whose church does not allow suspenders [in contrast to the other man, who is a] member of a one-suspender church" (ibid. 279).

At this point, a crucial question arises, namely, the one of accuracy of the Amish representations in literature and films when even such a small detail as wearing one or two suspenders makes a world of difference to an expert but obviously not to the writers, filmmakers and even less so to the audience. The latter became particularly noticeable after the release of some Hollywood blockbusters and television series which attracted a vast audience to the cinema, among them even the experts on Amish culture who openly voiced their opinion about the misleading pieces of information that the film and TV productions contained. It might be paradoxical but it is precisely because of the Amish's wish to remain separated from modern society that they keep attracting media attention and have appeared as leading characters in films, newspaper articles and fiction. Apart from throwing new light on the typology of Amish fiction, the article also centres on the representations of the Amish characters in literature, and the role which the Amish novels have in American culture. In the second part, the paper addresses some fundamental issues on the intentional distancing from the modern world on the part of the Amish community by creating boundaries through the use of their specific language and leading a sectarian way of life, concealed from the general public. Besides the secret fascination with the Amish, who are usually perceived as the 'Others', what will also be discussed is the role of film directors as cultural travellers when crossing cultural frontiers by entering the Amish cultural milieu.

${ }^{2}$ http://www2.etown.edu/amishstudies/FAQ.asp 
Ever since the publication of The Shunning ${ }^{3}$ in 1997, one of Beverly Lewis' contemporary novels featuring Amish characters, this religious minority has proved to be quite a popular theme in literature, especially in novels which are popularly being called 'Amish romance novels', but some journalists have gone even further and coined terms such as 'bonnet rippers' and 'chaste romances' that carry connotations ranging from witty to roguish. However this literary subgenre is facing some unaddressed questions regarding the system of its classification and naming. Labelling all of the fiction featuring Amish characters as Amish romance novels is questionable. First of all, not every novel on the Amish falls into this category even if there is an Amish character displayed on the cover of the book, especially because there are also Amish thrillers and mystery novels that can be found on the market, not just romantic literature centred on the Amish. Secondly, each of these novels carries its own label, ranging from contemporary fiction and general Christian fiction to contemporary romance and Christian romance. How come, then, that the name 'Amish romance novel' has been stuck uniformly to every novel describing the life of an Amish character in spite of John Morton's indubitable classification of Amish fiction as one of the subgroups within Christian fiction? The answer is a complex one. There seems to be a strong presence of a 'sense of being marginalized in a dominantly secular culture' (Gandolfo 2007, 53) among evangelicals and conservative Christians, and this combined with a well-known fact that the main publishers of Amish fiction happen to be evangelical Christian publishers whose 'Christian books, if reviewed at all [by the critics of the secular culture], are still treated with disdain as something less than "literature""(Gandolfo 2007, 57).

This apparent unpopularity of evangelicals which is projected also onto their publishing houses and the books they release on the market could partly explain why Amish fiction has earned a generalised and popularly used name Amish romance novel which attaches a negative connotation to every single fiction novel about the Amish. Even if the novels see to it that their plots unfold in accordance with the labels under which the books are advertised - some put more stress on the plot of the romance, whereas others concentrate more on the elements of the Amish life and their religious devotion - the publishers will have to take great pains to change this biased image where contemporary Christian fiction, and Amish fiction as its subgroup, is treated only as religious romance 'applying the conventions of the romance genre to spiritual experience' (Ganfoldo 2007, 116). Some critics say that this fiction also has all the characteristics of popular literature that is known to be a "light read" that makes few, if any, demands on the reader and can thus be a form of relaxation rather than study and concentration' (ibid. 67). However, claiming that every book dealing with an Amish character is a popular romance novel and thus automatically ascribing pejorative connotation to it and disregarding it completely, which is known to happen to other romance

\footnotetext{
${ }^{3}$ Although Beverly Lewis is considered to be the pioneering author of this genre, some novels centering on Amish culture had been published prior to Lewis' publication of The Shunning. The first one was Helen R. Martin's Sabina published in 1905. Lewis, however, is believed to be among the first ones, now followed by a group of over twenty (the number may even be bigger) other authors, who keep including the inspirational element in their fiction and thus remind the readers of the importance of living up to Christian standards on a daily basis, setting the Amish as a good example.
} 
novels too, is jumping to conclusion tantamount to saying that all Amish communities are homogeneous - an erroneous assumption based on lack of knowledge about the variety of Amish groups, since it is possible to find at least some Amish novels of good quality within the great bulk of repetitive material of the Amish fiction subgenre.

Amish novels are perceived as depicting the Amish people in a highly romanticised manner, but this is only true if we believe that all Amish people have the same personalities. Neither do all Amish (or any other people) have identical characters nor does all fiction depict only the positive side of the Amish people or their way of life, not even so-called 'Amish romance novels'. Putting just two novels featuring Amish characters under the magnifying glass we are guaranteed to find descriptions that are less than flattering to the Amish protagonists or their culture in general. Helen R. Martin's Sabina: A story of the Amish and W. Dale Cramer's Levi's Will are two novels as different as chalk and cheese, yet they both share one thing - they present at least one Amish protagonist who is not positively portrayed, and the same can be said of his or her culture. Sabina, originally published in 1905, is one of the earliest fiction novels dealing with the lives, locale, dress and customs of the Amish in local colour ${ }^{4}$ writing, which adds interest and authenticity to the plot. The Amish community in Martin's novel, however, is seen as having 'queer appearance' (Martin 2009, 25) and the main protagonist Augustus Acker, who is not Amish, finds the Amish women to be so 'pensive-looking, [that] they ma[ke] him think of caged animals transported to an alien clime' (ibid. 26). The outsider Augustus wants to spend time with an Amish family who has excited interest in him after seeing them at the Lancaster markets and get 'to know them in their native surroundings, to learn what [i]s the religion and what the life that produce[s] these odd people' (ibid.). The description given here does not place the Amish on a pedestal; rather, it puts them in the subordinate position of 'the Other' lacking refinement. Bad manners and no sophistication on the part of the Amish are even intensified when one of the male Amish characters displays what Augustus sees as clearly sexist behaviour. This occurs when the Amish man Levi makes no effort to help Aunt Susanna carry heavy rocking chairs in the house, 'for an Amishman's idea of the relation of the sexes is not unlike that of a North American Indian-it is the part of the female to wait on the male and make him comfortable. This, indeed, is the chief end of woman' (ibid. 54). Through Ackner, the artist with acute powers of observation, the author represents the Amish as strange people where especially women are denied many rights under the patriarchal dominance.

In Cramer's Levi's Will the portrayals of the Amish characters tend to rely on the experience of the author's father who left his community in his youth. In this novel, the descriptions of the Amish are more balanced. The author writes about childbearing in a negatively inclined way, and thus presents a view diametrically opposed to what would be a typical opinion regarding an Amish person. In a conversation about wives and kids, Will listened to another man who

'told them about a man he knew in Lancaster County whose first wife bore fourteen kids in the space of seven years - all twins and triplets. When she died he remarried - apparently right after the funeral - and his second wife was as fruitful as the first,

\footnotetext{
${ }^{4}$ Definition taken from Dictionary of Literary Terms and Literary Theory by J. A. Cuddon.
} 
spitting out babies like watermelon seeds. After fifteen years of marriage there were thirty-two children in the house' (Cramer 2005, 157-8).

As indicated in this quote, Cramer also writes about the gossipy nature of the Amish people, realistically presents some of their customs such as a funeral and a Sunday service, and what problems the Amish had to face being conscientious objectors during World War II in the midst of the dominant American society, which was very unsupportive of the Amish nonparticipation in combat, not knowing anything about their pacifist nature. Apart from shedding light on Amish culture, Levi's Will is also of significant importance for everyone who wants to gain historical and cultural insights into American society by further examining extra-textual references to Hershey's bar, Clark Gable, DiMaggio, the importance of the 60s and American attitude towards the Russians, Koreans and the Cold War. The accuracy and literary merit of these two and several other novels will be dealt in detail in my $\mathrm{PhD}$ dissertation, though one can expect marked differences between novels, depending on the authors' expertise in Amish culture and their flair for writing.

Most of Amish fiction gets published by evangelical or Christian publishers or their division such as Zondervan, WaterBrook Multnomah Publishing Group, Bethany House, Revell, etc. WaterBrook, for example, describes itself as the evangelical division of Random House,

'committed to creating products that both intensify and satisfy the elemental thirst for a deeper relationship with God. By communicating encouraging and life-enriching truths, WaterBrook Multnomah provides resources that can be trusted to be spiritually sound and readers will find to be captivating and enlightening. In providing these products as a Christian publisher, [they] hope that readers of all ages will gain a deeper understanding of God and live a life pleasing to Him. ${ }^{5}$

This is not an isolated case of how "the "billion-dollar book industry" of evangelical publishing houses and bookstores, developed in response to a de facto censorship of Christian literature' (Gandolfo 2007, 56) presents its vision to persuade the Christian readers in the value of rich spiritual life that can, so it seems, be achieved even when reading Amish fiction. It is not uncommon to hear the readers of Amish novels, in contrast to the readers of traditional romance novels, discuss that they do not experience any pangs of guilt while they are reading. This can be interpreted that even the vague sense of spirituality offered to the readers in the form of brief passages which describe Amish characters reaching out to God and God showing them his will is instantly deemed sufficient to meet the readers' religious needs. Another role that these novels perform is that they fulfil the readers' presumable wish to widen their horizons. Most of them, after all, would know that the next time they buy some cheese at an Amish stand they have to say 'danki', 'denki', or is it 'dankes' to thank the Amish salesperson in Pennsylvanian Dutch and ask about the state of health of the new 'Bobbeli' and its 'Mamm'. This subgroup of Christian fiction enables a brief glimpse into Amish culture,

\footnotetext{
${ }^{5} \mathrm{http}: / /$ waterbrookmultnomah.com/about-us/

${ }^{6}$ If three different authors write the expression 'thank you' in three different ways, it might be difficult for the readers to know which is the correct one.
} 
and thus allows its readers to explore the cultural frontier which might otherwise remain unexplored since it can be difficult to physically enter an Amish community, especially without any connections. The strong publishing industry and the authors, some of whom may personally know or be related to some Amish people, and the majority who have just done some research on Amish society and undertook writing novels, have partly disclosed the Amish culture to those interested in the subject. The readers are invited to follow further literary novelties on the market by either receiving books as freebies or seeing them promoted via numerous Facebook groups, personal Facebook profiles ${ }^{7}$, different blogs and radio talk shows such as Amish Wisdom on Toginet Radio. It seems that Amish novels have created a close-knit community of mostly middle-aged religious women sharing a passion for reading this type of fiction because they, too, can relate to the feeling of being marginalised in terms of being women within a patriarchal society and Christians within a secularized society. Their own subordination makes the Amish fiction with predominantly female characters of a religious minority group easy to identify with. Although the emergence of Amish fiction has not occurred as a direct reaction to the formulaic romance genre charged with sexual plot and graphic descriptions of love making, as depicted in Harlequin and Silhouette romances, it presents a refreshing change for the fans of romance novels who now enjoy the 'alternative to the secularizing influences of the dominant culture' (Gandolfo 2007, 65). The new type of novel featuring Amish protagonists, often categorised as inspirational or devotional novel, falls under Christian fiction and introduces what can be called a clean romance, which targets the readers with Christian religious values and religious background who cherish 'purity in values, faith and honesty' and also 'family time, togetherness, daily devotion [and] prayer times ${ }^{8}$ as one of the readers in my online survey suggested. Several responses from the survey revealed that during and after the act of reading, some readers may get a sense of embarking on a spiritual journey when drawing parallels between their religious experience and the one of the Amish character from the book. The Amish protagonists, who are usually presented positively, although this is not always the case, function as role models on how to become even better Christians, and sometimes the readers might even feel inclined to try to surpass the romanticised depiction of the Amish character. But most of all, these novels are clean and therefore not likely to offend the readers.

As far as the situation in Slovenia is concerned, the Slovenian publishing market has not yet picked up on this American literary phenomenon. However, it is intriguing to note that when I ordered some Amish fiction at a bookshop, the bookseller said she could not resist flicking through my selection of the books on the Amish, which she found an exciting read so much so that she was not able to put them down. There is a similar anecdote with Suzanne Fisher Wood's Amish Proverbs that I ordered via the same bookshop. When I got there to collect my book, I noticed that mine was not the only copy in the shop, there were at least five additional copies exhibited on the bookshelf proving that there is a certain kind of universal and immediate appeal that lies in the Amish way

\footnotetext{
${ }^{7}$ For more details, check: Amish Literature Fans, Amish Books Readers, and profile pages of authors Beverly Lewis, Wanda E. Brunstetter, Suzanne Woods Fisher, etc.

${ }^{8}$ https://docs.google.com/spreadsheet/viewform?formkey=dGIVd3JEYXRabUpRR09mZVY3X2c3bn c6MQ\#gid=0
} 
of life. Apart from my personal bookshop experience, there seems to be a relatively good supply of books about the Amish in Slovenian libraries. As far as fiction is concerned, Beverly Lewis, the author contributing greatly to the popularity of Amish fiction, is well represented with five novels, among them the renowned novel The Shunning from 1997 that actually paved the way for contemporary Amish fiction in the United States. Whereas Lewis's books have not yet been translated into the Slovenian language, there are at least Jodie Picoult's Plain Truth ${ }^{9}$ and Suzanne Woods Fisher's Amish Peace ${ }^{10}$ that Slovenian readers can enjoy in their mother tongue. Should one be interested in non-fictional and more in-depth representations of the Amish, great books to be found in Slovenian libraries are John Hostetler's Amish Society and Donald Kraybill's The Riddle of Amish Culture. Amish culture has also been inspiring to some of the Slovenian undergraduate students studying to obtain their BA. According to Co-operative Online Bibliographic System and Services (Cobiss), there are three students who dedicated their time to researching and getting an insight into the peculiarities of Amish culture in their BA theses ${ }^{11}$. However, none of them has ever spent time living in an Amish community, whereas Andreja Rustja, a theologian, tourist guide, journalist and a traveller, has. She described her unique experience in travelogues held in libraries all around Slovenia. Those who missed the opportunity to attend one of her picturesque presentations in front of a live audience can listen to her radio interview on RTV SLO ${ }^{12}$, although the recording cannot compete with her live performance in a real Amish dress.

Apart from their distinctive clothes there is another way through which the Amish have managed to maintain a gap between their and 'the English' ${ }^{13}$ culture, namely through the use of a specific dialect, called Pennsylvania German or Pennsylvania Dutch. It is surprising that even though the Amish wish to live secluded lives they speak not only their own language but are also fluent in English. Having their own dialect and mastering the language of the mainstream culture, in fact, stresses the need for "the differentiation between me and the other, between us and them, between those I feel close to and those I feel difficult to relate to" (Schubert 1999, 201). The underlying message being that when the Amish resort to the local dialect this clearly demonstrates that they are highly protective of their own culture and are strongly inclined to preserving their close-knit communities. This is particularly noticeable in the action-adventure television series MacGyver. In the third episode of season four, with a rather telling title The Outsiders, the tyre on MacGyver's car blows out, which results in his skidding off the road into a ditch where he ends up lying injured. As he begins to regain consciousness, the protagonist can faintly hear the voices of Amish men, muttering something in a language completely unintelligible to an outsider such as himself. It seems as if MacGyver not being fully conscious earns him the privilege of hearing what is supposed to be the Pennsylvania Dutch dialect, while being carried to one of the Amish homes.

\footnotetext{
${ }^{9}$ Translated as Preprosta Resnica by Ana Pogačar.

${ }^{10}$ Translated as Zgodbe o amiših by Neva Demšar.

${ }^{11}$ The three authors are Kamenšek Darja (Tradicionalna (manjšinska) verska skupnost v modernem okolju: primer amišev), Zlobec Vanja (Amiši: primer verskega tradicionalizma) and Hotko Ženja (Kulturnozgodovinski prikaz življenja skupnosti Amišev).

${ }^{12}$ http://tvslo.si/predvajaj/andreja-rustja/ava2.98148438/ (12. 3. 2012)

${ }^{13}$ According to the author David Weaver-Zercher, the label 'the English' 'is favored by many Amish persons' (Weaver-Zercher 2001, viii) when referring to the non-Amish people.
} 
Never again does the protagonist hear the sectarians' dialect, instead the Amish people represented in the series keep conversing strictly in English, which could be explained in two quite opposing ways. According to John A. Hostetler, once a leading scholar of Amish society, the Amish try to be considerate to non-Amish people and therefore whenever "an outsider dines with an Amish family, he may hear dialect chatter at the other end of the table, but out of courtesy, the general conversation will probably be in English" (Hostetler 1993, 242-243).

The other side of the coin, as one of my colleagues in the field experienced himself, is that the Amish are simply reluctant to share the Pennsylvania Dutch with 'the outsiders'. This is, to some extent, quite understandable, proving that the Amish are obviously aware of the fact that "languages have boundaries that [can] constitute limits of communication" (Schubert, 202) through which they can preserve their distinctive character and reject homogenization with relative ease. What an insurmountable boundary a language can present is well seen in the MacGyver series. In 1988 when the episode The Outsiders was released, the protagonist wants to make some jokes while repairing his damaged car. MacGyver utters "I'll make a grease monkey out of you" to one of the Amish female characters while she gives him a hand passing the tools over to him. The young woman gives him a puzzled glance, looking sheepishly in the direction of other Amish people, who are also helping MacGyver, to see what their reaction will be like. The event demonstrates how complicated it can be to enter a cultural sphere different from your own even with the use of humour, especially if it is not understood. On some other occasion, MacGyver is once again confronted with the lack of understanding on the part of the Amish concerning his jokes. The scene takes place just after his car was towed to the farm by Thunder, the Amish people's horse. MacGyver marvels at the horse's beauty and strength, asking "What do you feed him? Miracle-Gro?" to which he does not receive a response, obviously because the Amish have never heard of the brand name MacGyver uses to make a joke. It is evident that when the protagonist uses the intercultural reference Miracle-Gro ${ }^{14}$ for his joke, this has no informative value for the Amish people because of the cultural boundaries created by their way of living. As mentioned earlier, this may have been so in 1988 when the series was released, and the Amish were perhaps not that exposed to the mainstream culture. Nowadays, however, according to one of the readers of the blog Amish America, the Amish people "in [her] community know who all the Pooh bear characters are and [she] was shocked to hear they knew who Sponge Bob was! They didn't know that they were TV characters but they still knew who they were. [And she] found that kinda funny!" As can be understood from this blog post, the knowledge of the Amish is apparently not limited solely to their own culture, as the majority of people like to think. Another blog reader, working as a driver for the Amish contributes a self-explanatory post:

They $[\ldots$.$] have assimilated with our own culture quite well, referencing TV shows,$ music, current events, etc. They have a much greater knowledge of our culture than we do of theirs! Whenever a society is ignorant about a certain culture, myths are created and there remains a certain mystique to that culture, just as we have done with the Amish (ibid.).

\footnotetext{
${ }^{14}$ Scotts Miracle-Gro Company manufactures branded consumer products for lawn and garden care, and also provides products for professional horticulture.
} 
Apart from the Amish dialect, another element often represented in film or TV productions is religion, although not many film producers actually include an Amish religious service in their final product. Instead they rather focus on more conspicuous features of the Amish religion trying to shed light on their lifestyle. Referring back to MacGyver and The Outsiders, the television viewer can immediately turn to the most eye-catching idiosyncrasies of the Amish people: plain dressing, non-resistance and shunning of obdurate members of community. The way Amish people dress could, similarly as their dialect, be seen not only as a means of maintaining their cultural identity by expressing "obedience to God and [protest] to the proud and disobedient world" (Hostetler 1993, 237) but also their inclination to create boundaries between the members and non-members of their community. Because there are many subtle differences in Amish people's clothing between different communities, it is reasonable to conclude that actors' costumes are most of the time misleading. It is thus difficult to judge whether or not the Amish represented in The Outsiders are clothed in authentic attire.

In The Outsiders, Lee David Zlotoff's attempt to incorporate yet another cultural peculiarity of the Amish people, namely their inability to put up strong resistance, proves futile. The creator of the show introduces a bitter dispute between construction workers who want to relocate a local Amish family to new land in order to build a modern intersection on the Amish farm and thus create several new jobs in the region. The Amish family who have just begun digging a well on their farm clearly state that they have no intention of leaving the farm, explaining that "God put [them there] to tend [the] land [assuring the owner of the construction company that they] are not going to leave" (The Outsiders). Hostetler's study tackling the issue of non-resistance says that

The Amish have no rationale for self-defense or for defending their possessions [...] Hostility is met without retaliation. The Amish farmer who is in conflict with the world around him is admonished by his bishop to follow the example of Isaac: after the warring Philistines had stopped up all the wells of his father, Abraham, Isaac moved to new lands and dug new wells (Gen. 26: 15-18). This advice is taken literally, so that in the face of hostility, the Amish move to new locations without defending their rights (Hostetler 1993, 76).

The reaction of the Amish in the MacGyver series indicates that Zlotoff's representation is misleading for various reasons. First of all, judging by Hostetler's book the Amish would move if they were attacked, whereas in MacGyver they "have no intention of leaving the land" (The Outsiders). Moreover, it is even less likely to expect that the Amish would form a human chain as a way of showing their protest to the construction workers' plans to raze their home to the ground, which was seen in The Outsiders. What is correctly presented is that the Amish would never try to go to court to solve their problems, since this is "not [their] way, [they] do not know how to fight, even legally" (The Outsiders). What is intriguing, after all, is that Zlotoff makes an explicit biblical reference to Isaac digging another well, mentioned also in Hostetler's book.

One of the most riveting features of the Amish religious life presented in MacGyver is most likely the so-called Meidung or social avoidance, which was not represented even in such a controversial film as Witness. In The Outsiders, one of the younger Amish men 
is shunned on moral grounds. William is excommunicated from the Amish society as the result of his rebellion against traditional Amish values by running away and leaving the community without saying a word. During his two-month stay in Philadelphia, William supposedly went to movies, drove in automobiles and saw the city. MacGyver's spur-ofthe-moment reaction is "that sounds kinda normal for a guy his age" (The Outsiders). The protagonist's pointing out what the acceptable behaviour for a young person in his culture is like, is completely opposite to what is considered desirable of the Amish youth. William could only have explored the pleasures of the modern world had he been in his 'rumspringa', the period that literally translates as 'running around', when he would have been allowed to try out all the above mentioned activities. It is for purely commercial purposes that the media has often misrepresented this period as the time in the lives of the Amish youth when they are allowed to display some boisterous behaviour, such as consuming alcohol, abusing drugs and engaging in sexual intercourse, and in this way experience the real outside world. According to some popular representations, the end of the 'rumspringa' ultimately leads to a young person's decision to either get baptized in order to join the church or leave the Amish life altogether. This period is, in fact, not as wild in all of the communities as it usually gets presented in the mainstream media. There are only some communities in which the youth has built up a more unsavoury reputation, but generally, the period of 'rumspringa' is dedicated to joining a youth group and engaging in various social activities such as singing, playing volleyball, picnics, ice skating, etc., and it ends when a young person finds a lifelong partner with whom they are joined in a holy matrimony. In The Outsiders, the spectator is never offered a full insight into the Amish rules concerning social avoidance; however, according to Donald B. Kraybill, an expert on Amish groups, "Amish-born people who have never joined the church are not shunned. Only those who break their baptismal vow by leaving the church or falling into disobedience are ostracized" (Kraybill 1989, 116). One can, therefore, conclude that if William is punished for his two-month getaway, he must have been baptized and is now a full member of the Amish church. Had he been in his 'rumspringa' period, leaving the family for some time would not have led to such serious consequences as social avoidance.

For decades the film directors have been trying to represent the Amish way of life, but only some of their efforts were met with success. Reasons why they have been doing this may differ considerably, from making money to attracting audience's attention, which in the end results in earning a handsome profit. Many film directors have managed to cross the cultural frontiers, the invisible boundaries between two completely different cultural spheres and present to the non-Amish people the culture which has been ever so enthralling to them. At this point, a question arises as to what is so captivating about the Amish that they have been a topic of discussion for almost a century. Due to their secluded way of life, shaped by religious beliefs, specific dialect and dress code, the Amish have been perceived as such a different group that they have been labelled as 'the Others', despite being white and belonging to Anabaptist Christian denomination. However, their 'otherness' is still a compelling object of representation, strengthened by people's lack of knowledge about Amish culture. Bearing this in mind, the filmmakers keep whetting the audience's appetite for finally getting what they have been craving for by representing the supposed virtues of the Amish and their simple lives in a highly 
idealized way. Even in The Outsiders, MacGyver begins his journey to Pennsylvania describing it in a highly glorifying way, saying that:

There's just something about the Pennsylvania countryside. It smells clean and innocent. And after four weeks crammed inside a stuffy space simulator testing lab [his] senses needed to get reacquainted with nature. It's as close to paradise as you can get - fresh air, cool green trees, warm sunshine, and wildlife (The Outsiders).

If MacGyver feels so strongly about the Pennsylvanian nature, it is not surprising that he will have a similar attitude towards the Amish as well, perceiving them almost as an extension of nature. The way this series differs from other film and TV productions is that the Amish are presented both positively and negatively at the same time. MacGyver's behaviour shows that he highly cherishes the Amish for their generous help offered to him after the car accident, and pays them off by helping his hosts when they become involved in the dispute with the construction workers, and especially after helping to save both a non-Amish girl and her little Amish friend from an abyss. The builders, however, see the Amish as having 'thick skulls [and being] too good to mix with [them]' (The Outsiders), reproaching them for not taking part in wars. They insult the Amish that they do not follow the state's laws because they are not able to understand English (The Outsiders). But which of the two is the preferred meaning shown in the series if one takes into account that the spectator is presented with two binary opposing Amish depictions? In the beginning the Amish are portrayed as stupid people, only later on, with MacGyver's appearance and development of a friendly relationship with the Amish are they seen as positive characters. Obviously, the good wins; if not for any other reason it is because the tendency of MacGyver's series is to end on a positive note, leaving the audience with an encouraging message.

The Amish are paler than pale, they are whiter than white, but despite that they have been ascribed certain negative and positive stereotypes. Although there is a minority of people who openly admit to perceiving the Amish as a fundamentalist religious group, "an obscure sect living by ridiculous customs, as stubborn people who [have] resist[ed] education and exploited the labour of their children" (Hostetler 1993, 4), their voices tend to be heard on various forums. According to a colleague in the field, some Amish are even the victims of racism, because they are supposedly restricting other members' individual freedom. The negative aspect of the Amish life usually gets presented mostly in documentary films in order "to make a buck, and to convey newsworthy or culturally significant information" (Eitzen 2008, 45) by disclosing the less appealing side of the Amish way of life. This is another example of the Amish being exploited, since it is the documentary film directors who are in a position of power, but it is essential to take into consideration that 'power also involves knowledge, representation, ideas, cultural leadership and authority' (Hall 2000, 261). Since the nature of the Amish religious set of beliefs is such that they live humble lives, not being interested in the world around them and not willing to take part in changing it, their voices are kept unheard. The flip side of the Amish way of life, presented in documentary films, may to some extent help not just the greater part of the American society but other people who keep romanticizing the Amish, to learn the truth about this religious community that continues to be 
misrepresented in almost every single TV or film production. It is of utmost importance to realise that the Amish people, as any other minority group who have been ascribed certain characteristics and put in the role of the 'Other', are not necessarily better or worse, and certainly far from perfect. They come in all shapes and sizes and can have bad days and be grumpy.

The paper has, hopefully, raised awareness of the problems when categorising all Amish fiction under the label of 'Amish romance novels' which tries to mould all novels with Amish characters into a single unit, and represent the whole culture and its members in a romanticised way. The article has also illustrated the roles of the authors, publishers and readers of the novels, whereas the analysis of the MacGyver series centres on how Amish groups manage to keep their distance from the mainstream American society through the use of their specific language and religion which "is a total way of life, not a compartmentalized activity" (Hostetler 1993, 76), all of which helps to establish, not so much, real boundaries but imaginary ones. Since any kind of boundaries are often equated with the appeal of the unknown, some film directors have transformed themselves into cultural travellers in order to disclose the truth about the Amish way of life, hidden from the vast majority of people, but who have created an idealized mental picture of the Amish people and their lifestyle. It seems that there are some filmmakers who continue to portray idyllic perceptions of the Amish, but there are also creators of documentaries tackling the dark side of the highly romanticized people by depicting some Amish people's dissatisfaction with their supposedly perfect lives. Apart from bringing money to the filmmakers, both positive and negative representations try to fascinate, shock, and attract attention of the worldwide audience. It is up to the general public to finally realise that "all of life, including Amish life, comes not in 'black and white' but in 'subtle shades and hues of gray"' (quoted in Weaver-Zercher 2001, 19).

Ljubljana

\section{WORK CITED}

Cuddon, J. A. Dictionary of Literary Terms and Literary Theory. Penguin Books, 1992.

Eitzen, Dirk. "Reel Amish: The Amish in Documentaries." The Amish \& the Media. Ed. Diane Zimmerman Umble and David L. Weaver-Zercher. Baltimore: The Johns Hopkins University Press, 2008. Print. pp. 43-64.

Gandolfo, Anita. Faith and Fiction: Christian Literature in America Today. Westport: Praeger Publishers, 2007.

Hall, Stuart. "The Spectacle of the 'Other'." Representation: Cultural Representations and Signifying Practices. Ed. Stuart Hall. London: Sage; Milton Keynes: The Open University, 2000. Print. pp. 223-279.

Hostetler, John A. Amish Society. Baltimore; London: The Johns Hopkins University Press, 1993. Print.

Kraybill, Donald B. Riddle of the Amish Culture. Baltimore; London: The Johns Hopkins University Press, 1989. Print.

Mort, John. Christian Fiction: A Guide to the Genre. Greenwood Village: Libraries Unlimited. A Division of Greenwood Publishing Group, Inc. 2002. 
Rösler, Michael, and Tobias Wendl. Ed. Frontiers and Borderlands. Anthropological Perspectives. Frankfurt am Main: Peter Lang, 1999. Print.

Schubert, Klaus. "Frontier Languages, Language Boundaries." Frontiers and Borderlands. Anthropological Perspectives. Ed. Michael Rösler, Tobias Wendl. Frankfurt am Main: Peter Lang, 1999. Print. pp. 201-209. Print.

"The Outsiders." MacGyver: Third Episode, Fourth Season. Writ. Lee David Zlotoff and Michelle Poteet Lisanti. Dir. Michael Vejar. 1988. Online.

Weaver-Zercher, David. The Amish in the American Imagination. Baltimore: The Johns Hopkins University Press, 2001. Print.

Wesner, Erik. "Do we romanticize the Amish?” Amish America. Web. 26. April 2011. 